\title{
Water Pollution in Selected Coastal Areas in Western Province, Sri Lanka: A Baseline Survey
}

\author{
N. D. Hettige1, 2, \#, K. A. W. S. Weerasekara ${ }^{2}$, \\ S. A. M. Azmy ${ }^{2}$ and K. B. S. N. Jinadasa ${ }^{1}$ \\ ${ }^{1}$ Postgraduate Institute of Science, \\ University of Peradeniya, Peradeniya, Sri Lanka \\ ${ }^{2}$ Environmental Studies Division, \\ National Aquatic Resource Research and Development Agency (NARA), \\ Crow Island, Colombo 15, Sri Lanka \\ \# Corresponding Author: \\ Email: nadeeshahettige7@gmail.com
}

\begin{abstract}
The coastal area of the Western Province is faced with an acute environmental problem due to undesirable pollution of its waters from various wastes. The overall objective of this research was to determine the present status of water quality along the coastal line in the Western Province. In addition, an attempt was made to suggest recommendations to mitigate the pollution levels. The study was carried out from November 2011 to April 2012 and sampling was done on a monthly basis from Bentota to Negombo in selected coastal area. Dissolved oxygen (DO), water temperature, $\mathrm{pH}$, turbidity, conductivity, total dissolved solids (TDS) and salinity were determined in situ and water samples were subjected to laboratory analysis using standard methods. Coastal water quality results revealed that, the average ammonia concentration $(0.22 \pm 0.16) \mathrm{mg} / \mathrm{L}$ and water temperature $(30.0 \pm 3.8){ }^{\circ} \mathrm{C}$ were below the maximum permissible limits of the proposed ambient water quality standards for Sri Lankan coastal waters. Average pH $(7.91 \pm 0.34)$ was within the ideal $\mathrm{pH}$ range for above standards whereas the mean concentration of DO was below the saturation level. An average value determined for Biochemical Oxygen Demand (12.08 \pm 4.47$) \mathrm{mg} / \mathrm{l}$ was much higher than the permissible threshold limit (>5 mg/l) which indicates the gross organic and inorganic pollution in all selected sampling locations in western coast. Proposed ambient coastal water quality standards should be modified using coastal water quality monitoring data and expert views and comments. Further studies needed to determine heavy metal concentration and bacteriological parameters to obtain clear picture of the pollution status.
\end{abstract}

KEYWORDS: BOD, Estuary, Organic pollution 


\section{Introduction}

Deterioration of water quality is one of the main environmental problems in coastal and marine waters. Sri Lanka is acutely facing this problem mostly due to increased human population, rapid urbanization, industrial activities and intensive agricultural practices. Coastal areas of Sri Lanka are concentrated with high population and coastal population density is comparatively centered in Western Province due to high urbanization and therefore, is likely to be affected by the elevated concentrations of waste generated in the province.

Coastal water pollution is caused both by land based and sea based activities. In Sri Lanka, roughly $90 \%$ of marine pollution is on account of land - based and only $10 \%$ is sea - based (Prematunge, 2009). Agriculture, urbanization and industrialization are being considered as main land based activities where as ship accident, exploration and dumping of oil and garbage can be considered as sea based activities. Aquaculture practices also released contaminant to the marine environment. Western Province accounts for more than $60 \%$ of the total waste generated in Sri Lanka (UNEP, 2001).

Effluents are directly discharged to the water ways and finally its end up in the coast. And occasionally these effluents directly discharge into the sea. Therefore, coastal habitats are highly vulnerable to degradation. These destructed habitats are directly or indirectly negative impact to the marine biodiversity and finally threat to well - being of human. Therefore pollution prevention is an important for the utilization and management of these resources and it is an essential to determine the pollution of water quality of the coastal belt. Considering the above mentioned importance, this study mainly assessed the effect of coastal water quality in the Western Province, especially in the coastal area from Negombo to Bentota.

\section{Methodology}

\section{The Study Area}

The study was carried out monthly for a period of six months from November 2011 to April 2012. Sampling locations were selected using random sampling techniques with special reference to urbanized areas, tourist areas, industrialized areas which were subjected to fisheries and related activities in the Western Province. Accordingly, water samples were collected coastal sites that area located $200 \mathrm{~m}$ away from the shoreline. The Global Poisoning System (GPS) coordinates at the different locations and their site descriptions are given in Table 1. The relative sampling locations are illustrated in Figure 1. 
Table 1: Description of sampling locations of coastal area and their GPS coordinate

\begin{tabular}{|c|c|c|}
\hline Sampling Location & Position & Environment \\
\hline Kaluwamodara & $\begin{array}{l}\text { N } 6^{\circ} 26.562^{\prime} \\
\text { E } 79^{\circ} 59.254^{\prime}\end{array}$ & $\begin{array}{l}\text { Famous site for tourism, garbage accumulated } \\
\text { site, recreational site }\end{array}$ \\
\hline Kalutara & $\begin{array}{l}\text { N } 6^{\circ} 35.233^{\prime} \\
\text { E } 79^{\circ} 57.123^{\prime}\end{array}$ & $\begin{array}{l}\text { A coastal Park, near river mouth of Kalu } \\
\text { Ganga, garnet mix mineral sand }\end{array}$ \\
\hline Panadura & $\begin{array}{l}\mathrm{N} 6^{\circ} 42.678^{\prime} \\
\mathrm{E} 79^{\circ} 53.976^{\prime}\end{array}$ & $\begin{array}{l}\text { Coastal park, recreational site, polluted beaches } \\
\text { observed due to accumulated garbage }\end{array}$ \\
\hline Mount - Lavinia & $\begin{array}{l}\mathrm{N} 6^{\circ} 50.196^{\prime} \\
\mathrm{E} 79^{\circ} 51.755^{\prime}\end{array}$ & Famous site for tourist and recreational site \\
\hline Dehiwala & $\begin{array}{l}\text { N } 6^{\circ} 50.257^{\prime} \\
\text { E } 79^{\circ} 51.720^{\prime} \mathrm{E}\end{array}$ & $\begin{array}{l}\text { Fish boat landing site, garbage accumulated } \\
\text { beach }\end{array}$ \\
\hline Mattakuliya & $\begin{array}{l}\text { N } 6^{\circ} 58.698^{\prime} \\
\text { E } 79^{\circ} 52.218^{\prime}\end{array}$ & $\begin{array}{l}\text { Bathing site, beach park, higher amount of } \\
\text { garbage accumulated beach }\end{array}$ \\
\hline Dikkovita & $\begin{array}{l}\mathrm{N} 7^{\circ} 0.757^{\prime} \mathrm{N} \\
\mathrm{E} 79^{\circ} 51.475^{\prime} \mathrm{E} \\
\end{array}$ & Dikkovita fishery harbor, coastal developments \\
\hline Pamunugama & $\begin{array}{l}\mathrm{N} 7^{\circ} 4.734^{\prime} \mathrm{N} \\
\mathrm{E} 79^{\circ} 50.607^{\prime} \mathrm{E}\end{array}$ & Clean beach, fishing activities present \\
\hline Negombo Fish Market & $\begin{array}{l}\text { N } 7^{\circ} 12.764^{\prime} \\
\text { E } 79^{\circ} 49.775^{\prime} \mathrm{E}\end{array}$ & $\begin{array}{l}\text { Fishing boat landing site, presence of fish } \\
\text { market }\end{array}$ \\
\hline Negombo Park & $\begin{array}{l}\mathrm{N} 7^{\circ} 14.233^{\prime} \mathrm{N} \\
\mathrm{E} 79^{\circ} 50.174^{\prime} \mathrm{E}\end{array}$ & Tourist and recreational site \\
\hline
\end{tabular}

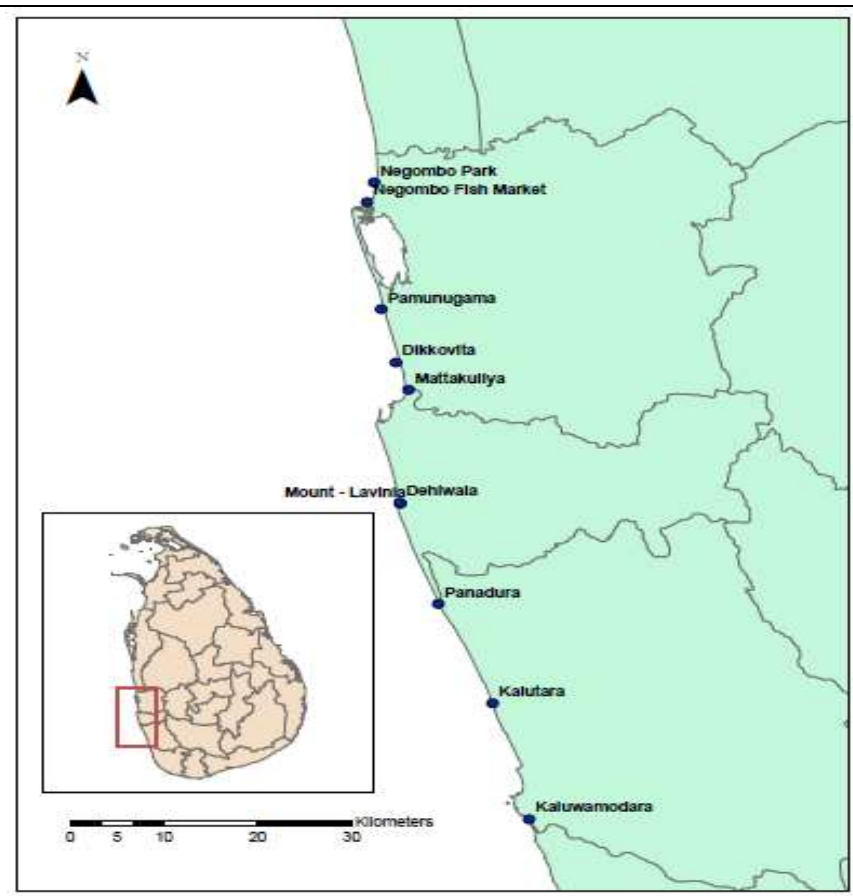

Figure 1: Map of sampling locations 


\section{Sample Analysis}

Electrical Conductivity (EC), Total Dissolved Solids (TDS), salinity and water temperature were measured using Hanna portable multi range conductivity meter (HI 8733). Concentration of DO and $\mathrm{pH}$ were measured using Orion 830A oxygen meter and Orion 260A pH meter respectively whereas portable HATCH meter (model 2100P) was used to measure turbidity.

Water samples processed in the field were subjected to laboratory analysis using standard methods (APHA, 2005). The samples were analyzed for various water quality parameters namely TSS, ammoniacal-N, ortho-phosphate, nitrate-N, nitrite$\mathrm{N}$, oil and grease and chlorophyll-a. In addition, BOD was measured using Aqua Lytic BOD sensors. Data was analyzed using the Microsoft Excel 2007 program where the minimum, maximum, average and standard deviation values were calculated for the different water quality parameters.

\section{Results and Discussion}

Table 2 presents the minimum, maximum, mean and standard deviation of the overall results recorded from coastal area.

Table 2: Overall results

\begin{tabular}{lcccc}
\hline \multicolumn{1}{c}{ Parameter } & Minimum & Maximum & Mean & St.div \\
\hline Water temperature $\left({ }^{\circ} \mathrm{C}\right)$ & 28.0 & 33.3 & 30.5 & 1.4 \\
\hline $\mathrm{pH}$ & 6.55 & 8.45 & 7.91 & 0.34 \\
\hline Salinity $(\mathrm{ppt})$ & 0.90 & 34.80 & 29.95 & 9.08 \\
\hline EC (mS/cm) & 1.79 & 52.7 & 41.04 & 14.86 \\
\hline TDS (g/l) & 0.89 & 33.40 & 26.91 & 8.39 \\
\hline DO (mg/l) & 5.22 & 7.75 & 6.38 & 0.56 \\
\hline Turbidity (NTU) & 2.52 & 28.4 & 7.62 & 4.70 \\
\hline Ammoniacal - N (mg/l) & 0.01 & 0.73 & 0.22 & 0.16 \\
\hline Nitrate (mg/L) & 0.00 & 0.19 & 0.02 & 0.03 \\
\hline Nitrite - N (mg/l) & 0.00 & 0.04 & 0.01 & 0.01 \\
\hline Phosphate (mg/l) & 0.00 & 0.01 & 0.03 & 0.02 \\
\hline BOD (mg/l) & 3.00 & 21.00 & 12.08 & 4.47 \\
\hline
\end{tabular}




\begin{tabular}{lcccc}
\hline TSS $(\mathrm{mg} / \mathrm{l})$ & 2.40 & 18.40 & 10.70 & 4.03 \\
\hline Chlorophyll $-\mathrm{a}(\mu \mathrm{g} / \mathrm{l})$ & 0.16 & 7.31 & 1.88 & 1.29 \\
\hline Oil and grease $(\mathrm{mg} / \mathrm{l})$ & 3.00 & 51.10 & 18.52 & 9.65 \\
\hline
\end{tabular}

An average concentration of Ammoniacal - $\mathrm{N}$ in Negombo fish market coastal area was highest $(0.46 \pm 0.12) \mathrm{mg} / \mathrm{l}$ and lowest average in the sampling location of Panadura coastal area $(0.10 \pm 0.07) \mathrm{mg} / \mathrm{l}$ (Figure 2). Average Ammoniacal - $\mathrm{N}$ at Mattakuliya $(0.44 \pm 0.06) \mathrm{mg} / \mathrm{l}$ and Negombo fish market $(0.46 \pm 0.12) \mathrm{mg} / \mathrm{l}$ coastal area were above the threshold limits of proposed ambient coastal water quality standards. Mattakuliya coastal area receives both liquid and solid waste mainly from Kelani River estuary and Mutuwal sea outfall. However, this outfall is under construction at most of the time. It had been happened during the study period. Also Mattakuliya beach area is used by local people as recreational site. According to the several studies, ammonia concentration is comparatively high Kelani Ganga estuary. Therefore Mattakuliya coastal area is polluted due to the Kelani Ganga estuary. Negombo fish market area is polluted due to the discharge of fish waste directly to the coastal area. Most of the dwellers living along the coastal area do not have any toilet facilities and use the beach as toilet. Furthermore, recent studies have revealed that, coastal area of Western Province has been polluted due to high ammonia concentration.

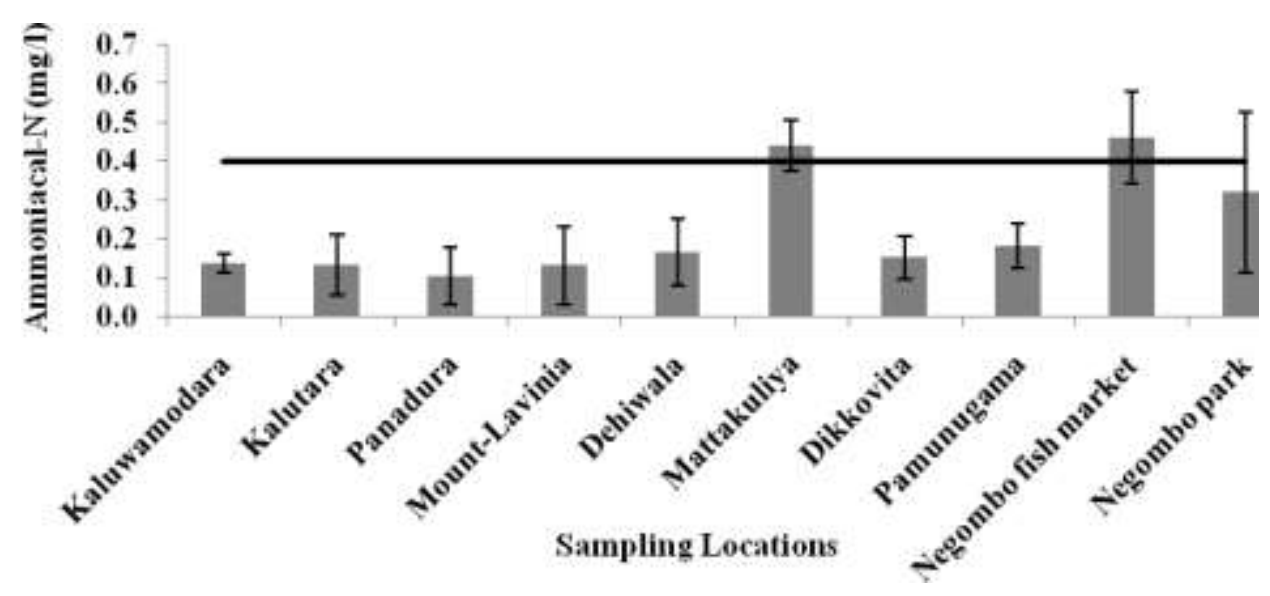

Figure 2: Variation of Ammoniacal - N

Maximum average concentration of phosphate $(0.06 \pm 0.03) \mathrm{mg} / \mathrm{l}$ was recorded from Negombo fish market coastal area where as lowest average concentration of ortho-phosphate $(0.017 \pm 0.01) \mathrm{mg} / \mathrm{l}$ was noticed from Panadura coastal area (Figure 3). There is no permissible limit for ortho - phosphate in the proposed ambient coastal water quality standards. 


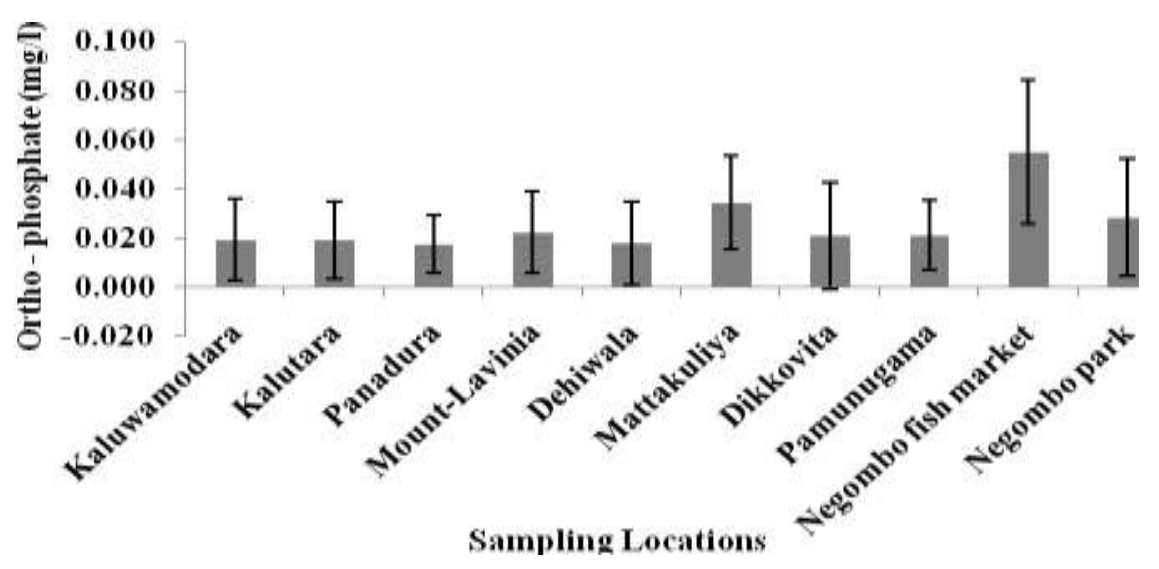

Figure 3: Variation of ortho - phosphate

Highest average concentration of Nitrate $-\mathrm{N}(0.07 \pm 0.06) \mathrm{mg} / \mathrm{l}$ and nitrite concentration $(0.02 \pm 0.01) \mathrm{mg} / \mathrm{l}$ were recorded from Mattakuliya coastal area where as lowest average concentration of nitrate $(0.008 \pm 0.003) \mathrm{mg} / \mathrm{l}$ and nitrite concentration $(0.005 \pm 0.002) \mathrm{mg} / \mathrm{l}$ were recorded from Panadura coastal area (Figure 4). Excessive use of nitrate fertilizers and runoff from human and animal waste are the main sources which affect to the variation of nitrate in water. Also Amarasiri (2007) stated that the large amount of nitrogenous fertilizers has contributed to increased high levels of nitrate in water in many countries. Agricultural runoff from upper catchment of the Kelani Ganga and discharges from Mutual sea outfall would be reason for the recorded nitrate at the Mattakuliya coastal area. Aquaculture operations, especially finfish farms where food is added, can be important sources of nitrogen inputs in coastal areas where this activity occurs (Merceron et al., 2002). This is relevant to the Negombo coastal area.

Highest average concentration of BOD was $(16.50 \pm 1.38) \mathrm{mg} / \mathrm{l}$ recorded from Dikkovita coastal area during the study period. However lowest average concentration of BOD was $(6.83 \pm 1.94) \mathrm{mg} / \mathrm{l}$ recorded from Kalutara coastal area (Figure 5). Average concentrations of BOD in all the coastal locations were above the coastal water quality standards. Recorded BOD values indicate the gross organic and pollution states all selected locations. Fishing activities generate effluents having a high $\mathrm{BOD}$ and it is main reason for the recorded BOD concentration at the Negombo fish market coastal area. Dikkovita is mainly near to the Colombo habour. Coastal water can be flowed from Colombo habour to Dikkovita coastal area due to the direction of vertical and horizontal water current. The Colombo harbour is faced with an acute environmental problem with a threat of undesirable pollution of its waters from oil, liquid and solid wastes. Therefore it would be the recorded high BOD in Dikkovita coastal area. Dissanayake and De Alwis (2011) have been found organic pollution in some selected western and southern coastal sector of Sri Lanka in 2008. 


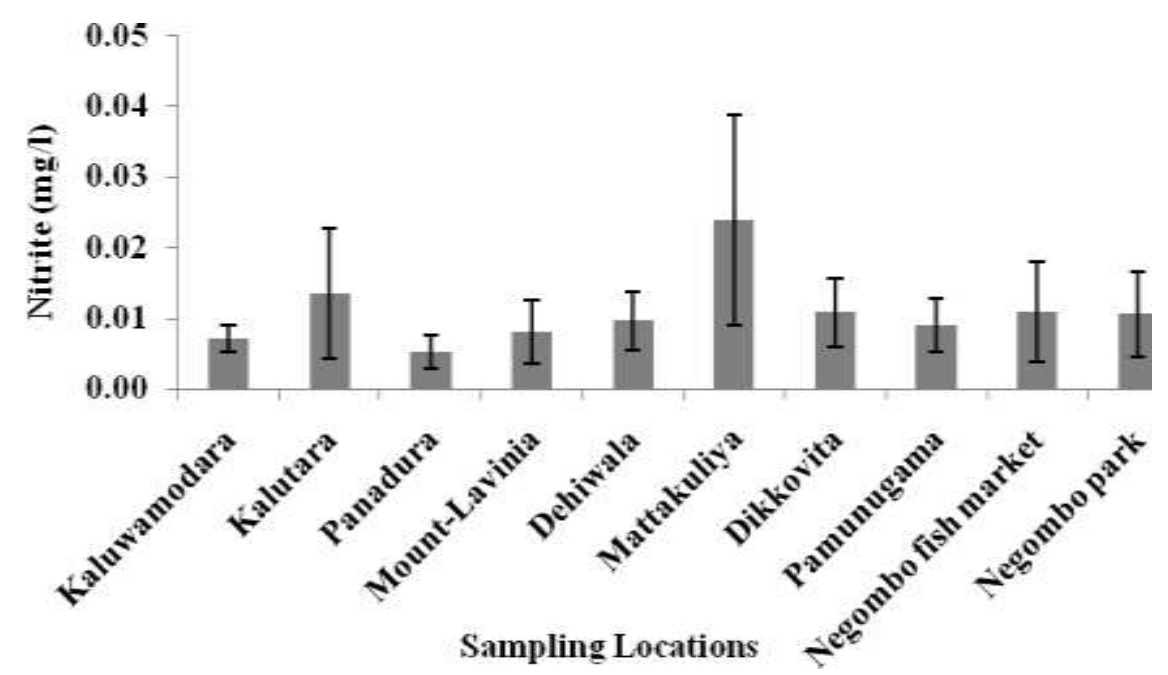

Figure 4: Variation of Nitrate - $\mathrm{N}$

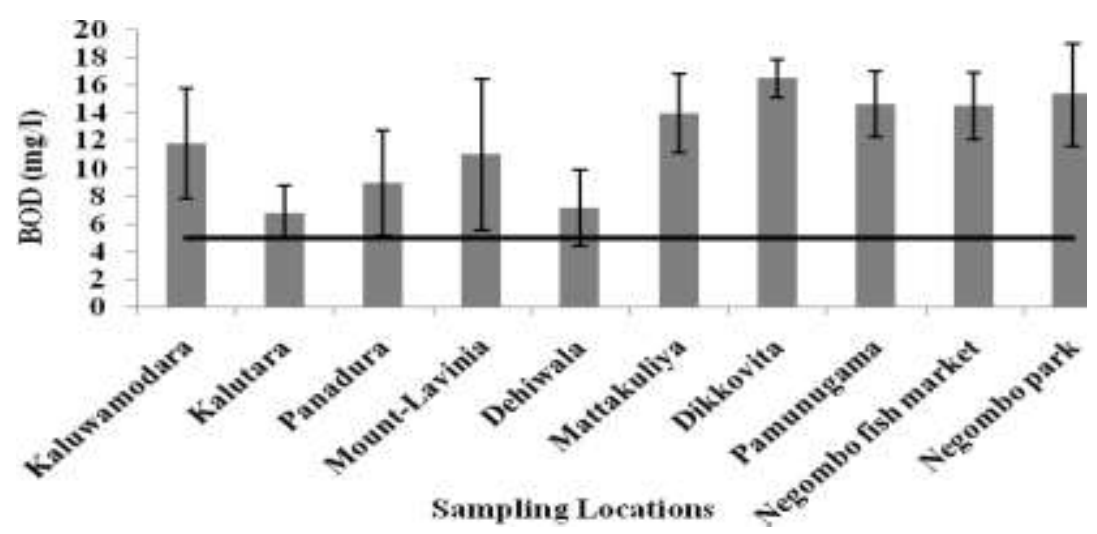

Figure 5: Variation of BOD

Negombo fish market coastal area was recorded the highest TSS level (13.32 \pm $3.24) \mathrm{mg} / \mathrm{l}$ and lowest average TSS was $(6.70 \pm 3.87) \mathrm{mg} / \mathrm{l}$ recorded from Kaluwamodara coastal area (Figure 6). Maximum average turbidity was (11.62 \pm 4.69) NTU recorded in Negombo park coastal area throughout the study period. And the lowest average turbidity $(4.40 \pm 1.43)$ NTU was recorded from coastal area of Mount - Lavinia (Figure 7). Excessive siltation and sedimentation has been reported in estuaries and coastal waters in Sri Lanka mainly due to the river runoff carrying sediment, agricultural and industrial wastes and products of upland soil erosion. Similarly industrial and domestic sewage from industries and human 
settlements outskirts of estuaries and in the coastal belt are attributed to further increase of siltation and sedimentation (UNEP, 1986). TSS and turbidity are changed due to the watershed hydrologic process, soil sediment characteristics and land use pattern (Amarathunga et al., 2010). The high turbidity and TSS can be caused either by extensive soil erosion within the watershed and it flow in to the coastal water through river or canal. Finally it is markedly depend on the tidal pattern. The turbidity can be increased in the coastal region due to a rise of the river and flux from river is closely related to precipitation (Fukuda et al., 1975). Turbidity and TSS were higher during the rainy season and low levels were determined during the dry weather condition. However, there is no specific standard for coastal waters in Sri Lanka to compare the present results of TSS.

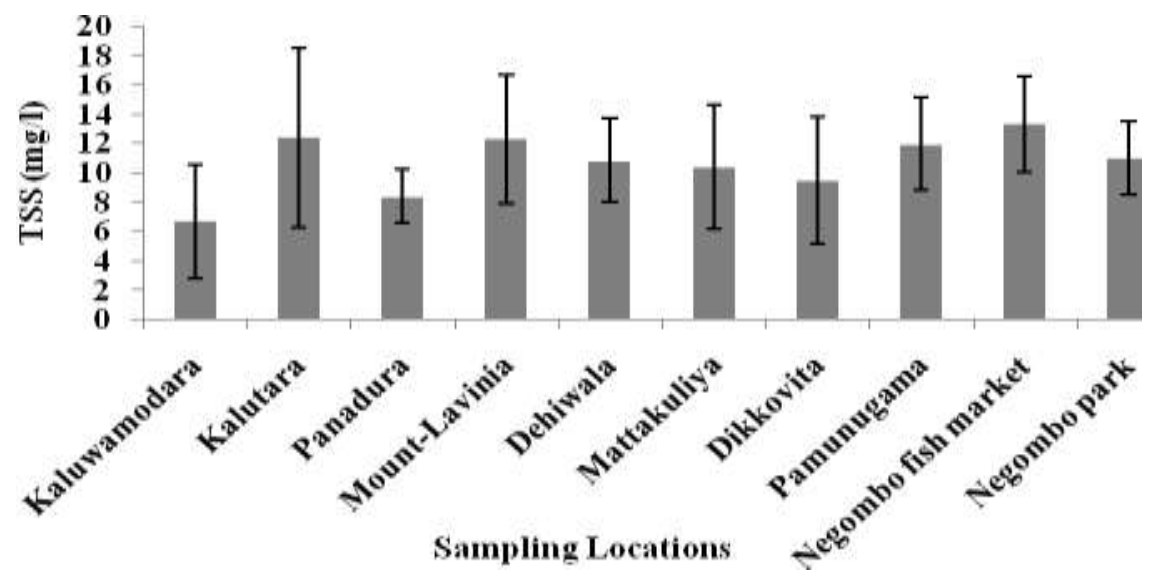

Figure 6: Variation of TSS

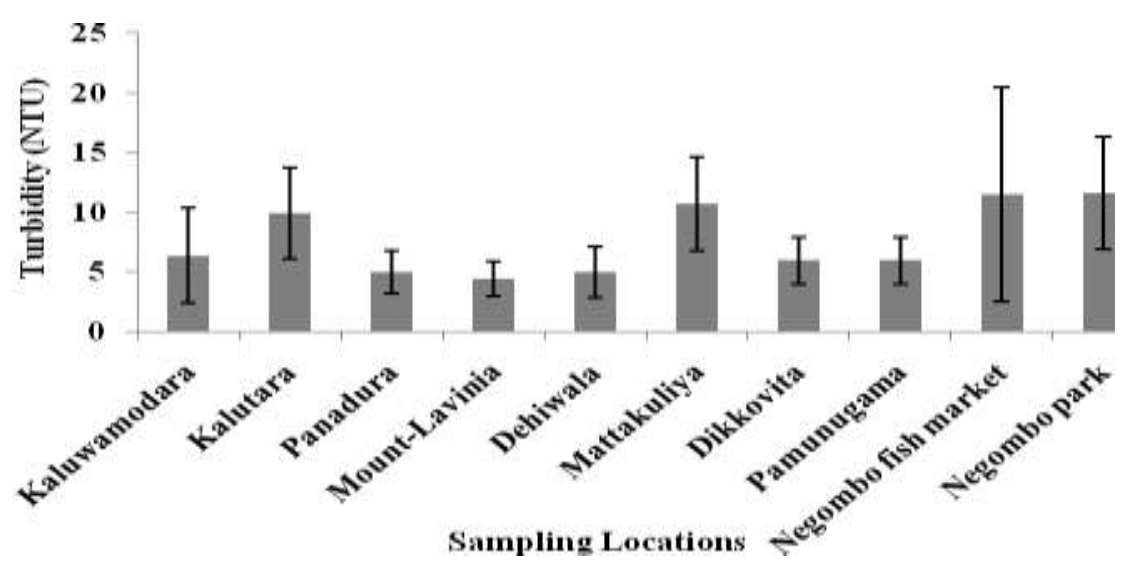

Figure 7: Variation of turbidity 
Lowest average chlorophyll - a was recorded from sampling location of Negombo fish market area $(1.15 \pm 0.64) \mu \mathrm{g} / \mathrm{l}$. And the highest average chlorophyll - a concentration $(2.78 \pm 1.87) \mu \mathrm{g} / \mathrm{l}$ was noted from Dehiwala coastal area (Figure 8). It is natural for chlorophyll a levels to fluctuate over time. Chlorophyll a concentrations are often higher after rainfall, particularly if the rain has flushed nutrients into the water. Higher chlorophyll a levels are also common when water temperatures and light levels (NLWRA, 2008). Dehiwala coastal area indicated high productivity due to the highest concentration of chlorophyll a compare to the other locations. Dehiwala Canal is directly discharging water in to the sea. According to the Anon (2011), Phosphate and BOD concentrations are relatively high in Dehiwala Canal water which indicates nutrient enrichment due to disposal of domestic and industrial wastewater into the canal over time. Therefore it is clear that the nutrient enrichment in Dehiwala coastal area due to the discharges from Dehiwala Canal.

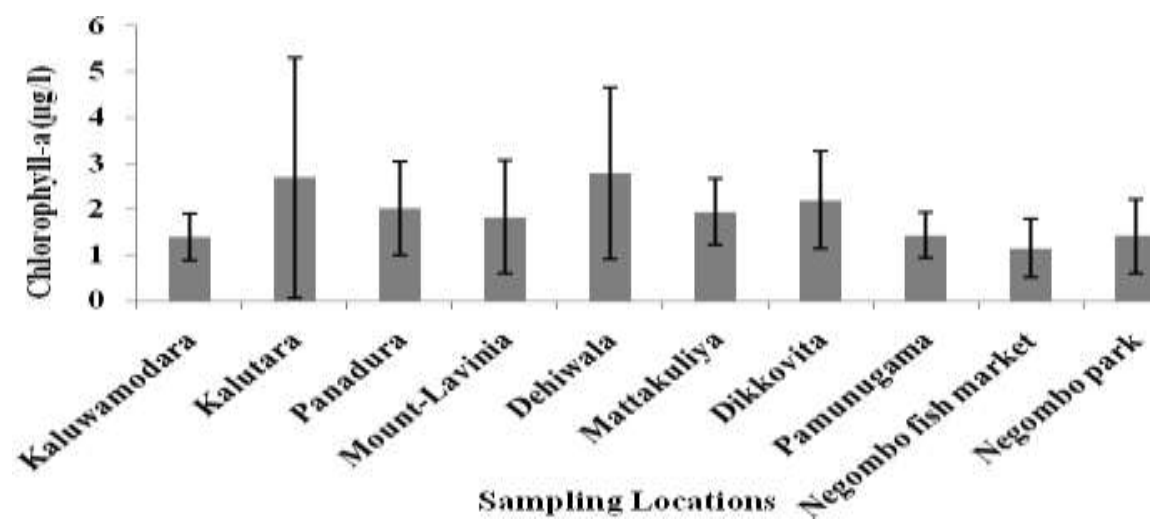

Figure 8: Variation of Chlorophyll - a

Maximum average concentration of $\mathrm{pH}$ was $8.12 \pm 0.11$ recorded from Pamunugama coastal area. And average lowest value recorded was $7.53 \pm 0.47$ from Kaluwamodara coastal area (Figure 9). Recorded average $\mathrm{pH}$ values are indicated slightly alkaline conditions. Runoff such as fertilizers and detergents from upper catchment of the inland water bodies cause increased alkalinity in water at the coastal area. Also effluent from the tourist hotels, aquaculture farming would be reason for the recorded alkaline condition of the coastal water. Pamunugama is situated left side of the Colombo habour. Coastal water can be poured from Colombo habour to Pamunugama coastal area due to the direction of vertical and horizontal water current. Colombo habour water is mainly polluted from shipping and anthropogenic activities. Therefore it would be the recorded high $\mathrm{pH}$ in Pamunugama coastal area. 


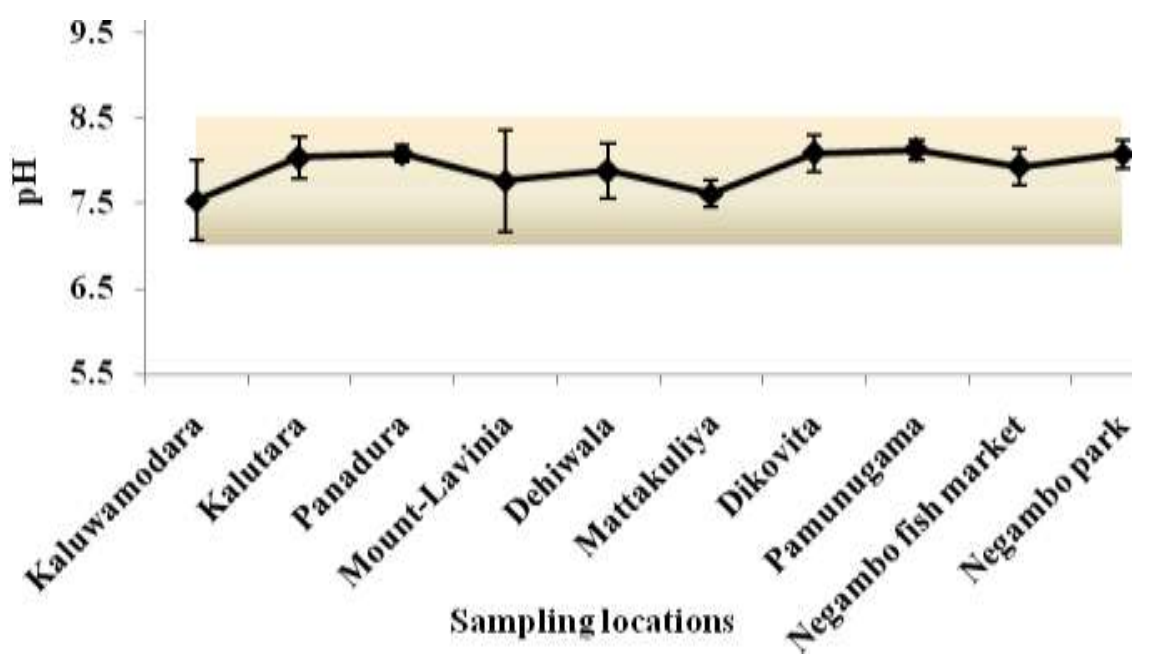

Figure 9: Variation of pH

The lowest average oil and grease was $(12.17 \pm 1.72) \mathrm{mg} / \mathrm{l}$ recorded from coastal area of Mount Lavinia where as highest average value was $(28.00 \pm 15.31) \mathrm{mg} / \mathrm{l}$ recorded from Mattakuliya coastal area (Figure 10). Discharges enter though rivers, leakages from ships, boats may have significantly contributed to the oil and grease content in coastal area. Most of the oil floated in the surface water is contributed to damage eggs of aquatic organisms, plankton as well as filter feeding fish. The chemical alteration of habitat, destruction of coral and the destruction of mangroves could be caused by oil pollution (UNEP, 1986).

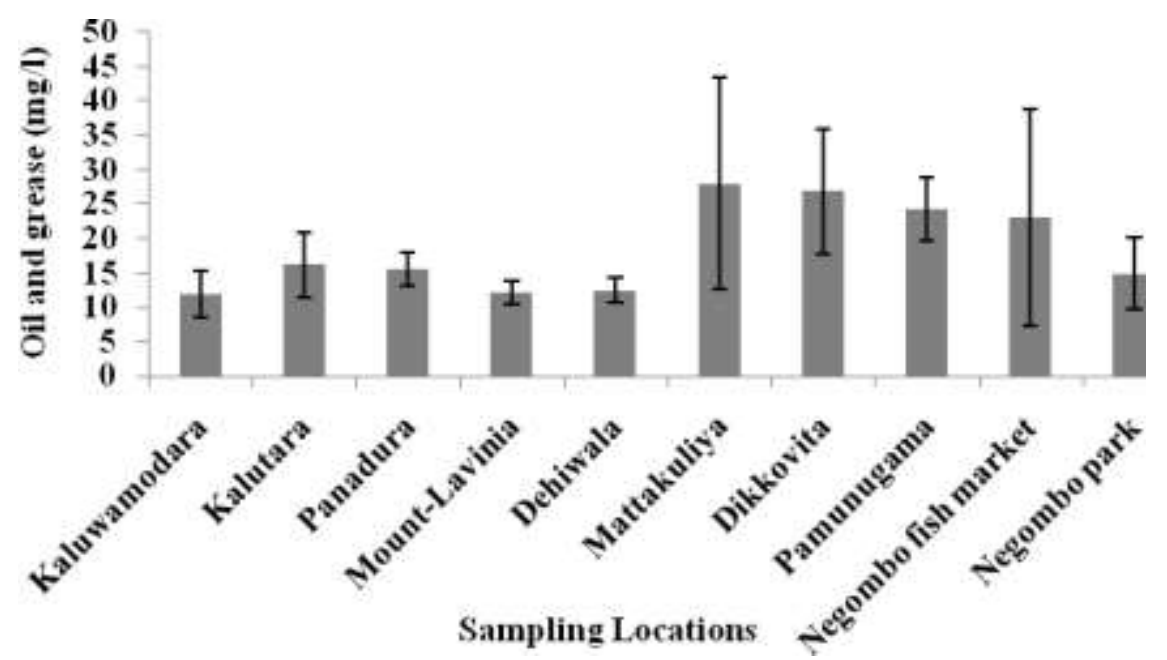

Figure 10: Variation of oil and grease 
The highest average concentration of DO value was recorded from sampling location of Mount Lavinia $(6.74 \pm 0.68) \mathrm{mg} / \mathrm{l}$ and lowest concentration $(6.14 \pm 0.57)$ $\mathrm{mg} / \mathrm{l}$ was noticed from the sampling location of Negombo fish market coastal area. However, Recorded average concentration of DO in coastal area was $6.38 \pm 0.56$ $\mathrm{mg} / \mathrm{l}$ (Table 2).

Highest average salinity value $(32.78 \pm 1.45)$ ppt was recorded from Dikkovita coastal area and a lowest average value $(9.60 \pm 8.84)$ ppt was recorded from coastal area of Kaluwamodara. But an average salinity of value of coastal area was (27.95 \pm 9.08) ppt. Coastal water salinity is changed due to the several factors namely evaporation, precipitation and fresh water runoff from the rivers or canals (Garrison, 2004). Kaluwamodara $(9.60 \pm 8.84) \mathrm{ppt}$ and Mattakuliya $(15.30 \pm 8.37) \mathrm{ppt}$ are recorded lower salinity values compare to the other locations. Fresh water runoff from the Bentara River and Kelani River would be reason for recorded low salinity in these two locations. According to Dissanayake and De Alwis (2011), salinity is within the threshold limits of proposed ambient coastal water quality standards.

\section{Conclusion}

Coastal water quality results revealed that, the average ammonia concentration $(0.22 \pm 0.16) \mathrm{mg} / \mathrm{L}$ and water temperature $(30.0 \pm 3.8)^{\circ} \mathrm{C}$ were below the maximum permissible limits of the proposed ambient water quality standards for Sri Lankan coastal waters. Average $\mathrm{pH}(7.91 \pm 0.34)$ was within the ideal $\mathrm{pH}$ range for above standards whereas the mean concentration of DO was below the saturation level. An average value determined for BOD $(12.08 \pm 4.47) \mathrm{mg} / \mathrm{l}$ was much higher than the permissible threshold limit $(>5 \mathrm{mg} / \mathrm{l})$ which indicates the gross organic and inorganic pollution in all selected sampling locations in western coast.

\section{Recommendations}

Based on the field investigations and laboratory analysis of this research following recommendations can be made in order to minimize the impacts of deterioration of coastal water quality from land based activities in Sri Lanka. When discharging industrial effluents into water bodies, given standards limit for discharge of effluents into inland and marine surface waters should be thoroughly followed, Proposed ambient coastal water quality standards should be modified using coastal water quality monitoring data and expert views and comments, Awareness programs about coastal pollution should be conducted for coastal communities including fishermen and school children, Improve the public health to increase sanitation such as providing latrine facilities for people in the vicinity of the coastal area, as it will have an impact on the aquatic health of the marine environment, Proper monitoring programs should be initiated for identification of water pollutant sources, which discharge pollutants in to the marine waters directly or indirectly and actions should be taken to prevent further damage to the marine environment, Proper coordination should be created among government and nongovernmental organizations to minimize the effect of pollution from the land based activities, 
Regulation should be implemented to minimize the pollution from tourism, harbours and ports activities.

\section{Acknowledgment}

The authors are thankful to the National Aquatic Resources Research and Development Agency for providing funds to carry out this research project and they would like to be grateful to Postgraduate Institute of Science for providing permission to carry out this research project

\section{References}

Amarasiri, S. (2007). "Declining water quality and its effect on water security". Symposium Proceedings of the Water Professionals' Day, Geo Informatics Society of Sri Lanka (GISSL).

Amarathunaga, A. A. D., K. A. W. S. Weersasekara, N. Sureshkumar, R. R. A. R. Shirantha and S. A. M. Azmy (2010). "Total Suspended Solids and Turbidity co-relation and its impact on aquatic community in Kotmale sub-catchment in the Upper Mahaweli Watershed in Sri Lanka". Symposium Proceedings of the Water Professionals' Day, Postgraduate Institute of Agriculture and Geo Informatics Society of Sri Lanka (GISSL).

Anon. (2001). "Pollution of inland waters, state of the environment". Available from: http://www.rrca. ait.asia/reports/soe/srilankacoastal.pdf [Accessed 10 September 2013].

Anon. (2011). "Environmental screening report for embankment protection of Dehiwala canal from the Galle road bridge to close to the sea outfall and removal of localized rock outcrops from the canal bed". Metro Colombo Urban Development Project. Available from: http://www. defence.lk/news/pdf/DehiwalaCanal.pdf [Accessed 11 November 2013].

APHA. (2005). "Standard methods for the examination of water and waste water". $20^{\text {th }} \mathrm{Ed}$. APHA/AWWA/WEF.

CEA. (1992). "Environmental quality standards and designation of water use in Sri Lanka". Government of the Netherlands Ministry of Foreign Affairs and Government of the Sri Lanka Ministry of the Environment and Parliamentary affairs, 34-39.

Dissanayake, D. M. P. S. and A. De Alwis (2011). "A baseline survey on eutrophic status of coastal waters in some selected western and southern coastal sector in Sri Lanka". Proceedings of the 16th International Forestry and Environment Symposium, Department of Forestry and Environmental Sciences, University of Sri Jayewardenepura, Sri Lanka.

Garrison, T. (2004). "Essential of Oceanography". $3^{\text {rd }}$ Ed. Thomson Learning 511 Forest Lodge Road, Pacific Grove, CA 93950, USA, 113. 
Merceron, M., M. Kempf, D. Bentley, J. D. Gaffet, J. LeGrand and L. Lamort-Datin (2002). "Environmental impact of a salmonid farm on a well flushed marine site; I. Current and water quality." J. Appl. Icthyol, 18: 40-50.

Prematunge, S. (2009). "Earth Hope". Available from: http://ww w.sundayobserver.lk /2009/04/05/rev12.asp [Accessed 5 January 2012].

UNEP. (1986). "Environmental problems of the marine and coastal area of Sri Lanka: National Report, UNEP Regional Seas Reports and Studies No. 74". 